\title{
Wetland Saline Water and Acid Mine Drainage Desalination by InterlayeFree Silica Pectin Membrane from Banan Peels
}

\author{
Muthia Elma ${ }^{1,3} *$, Akhbar ${ }^{2,3}$, Fitri Ria Mustalifah ${ }^{2,3}$, Lilis Suryani ${ }^{2,3}$, Erdina Lulu Atika Rampun ${ }^{3}$, \\ Aulia Rahma ${ }^{3}$ \\ ${ }^{1}$ Chemical Engineering Department, Faculty of Engineering, Universitas Lambung Mangkurat, Banjarmasin \\ 70123, Indonesia \\ ${ }^{2}$ Environmental Engineering, Faculty of Engineering, Universitas Lambung Mangkurat, Banjarmasin 70123, \\ Indonesia \\ ${ }^{3}$ Material and Membrane Research Group, Faculty of Engineering, Universitas Lambung Mangkurat, Banjarma- \\ $\sin 70123$, Indonesia
}

*Corresponding author:

E-mail: melma@ulm.ac.id

\begin{abstract}
Wetland water and acid mine drainage are available in South Kalimantan, Indonesia. However, "Wetland saline water (WSW)" phenomena occur in the wetland areas due to the seawater intrusion, this water which contains a high salt concentration is unsafe to be consumed. While acid mine drainage (AMD) pollution becomes an issue in the mining industry that impact human life and the environment. Salt particles could be removed by using a silica pectin membrane. Banana peel has a high pectin substance. Banana pectin $(0.5 \mathrm{wt} \%$ and $0.1 \mathrm{wt} \%)$ was employed in silica and calcined at 300 and $400^{\circ} \mathrm{C}$. We demonstrate the silica pectin template's performance without interlayer for wetland water and acid mine drainage desalination. Membranes were developed through a sol-gel method with silica source deposited from tetraethyl orthosilicate (TEOS) and performed by pervaporation at room temperature $\left(25^{\circ} \mathrm{C}\right)$. As a result, $0.5 \mathrm{wt} \%$ banana pectin concentration at $300^{\circ} \mathrm{C}$ exhibited excellent performance with the highest water fluxes are 8.4 and $10.4 \mathrm{~kg} \mathrm{~m}^{-2} \mathrm{~h}^{-1}$ for WSW and AMD, respectively. Nevertheless, both membranes achieved high salt rejections up to $92 \%$. Thereby, banana pectin as a carbon source impacts the stronger silica bond.
\end{abstract}

Keywords: Acid mine drainage, desalination, silica pectin membrane, wetland saline water

\section{Introduction}

Poor water quality caused by seawater intrusion and mine activities may affect the aquatic and human living. In South Kalimantan, Indonesia the massive mining industries play important roles in the economy. However, acid mine drainage (AMD) is formed as their product. During the rainy season, the water is mixed with coal at the mined coal and may run off to surface water (Nurofiq et al., 2016). On the other hand, wetland saline water (WSW) in South Kalimantan has become a serious problem that should be solved. WSW salinity is even reached 40,000 ppm (3.5wt\%) (Rampun, Elma, et al., 2019b). This value is found to be worst in the dry season because the water gets evaporated, and more salt remains in the water. Hence, desalination by pervaporation can be applied.

In principle, pervaporation is the separation of the mixture process by partial vaporization, which involves membrane (non-porous or porous). To apply low pressure, a vacuum pump is required (Rampun et al., 2019b, Van der Bruggen \& Luis, 2015). The pervaporation driving force is worked through chemical potential related to the concentration gradient between phases side by side of the interfacial barrier 
(Crespo \& Brazinha, 2015). Various membrane-type have been used in pervaporation such as silica (Rahma et al., 2019a), aluminum-rich zeolite beta incorporated sodium alginate (Adoor et al., 2008), and polydimethylsiloxane (Kaddour et al., 1998).

Among all types of membranes, silica has excellent mechanical strength and thermal stability. The unique characteristic of silica materials are physiochemical properties which consist of cross-linked network structure (Diniz Da Costa, 2000, Ellis, 2004), high surface area (Elma et al., 2019), and vigorous (Elma, Riskawati, Marhamah, 2018). Owing to these properties, silica has been gaining widespread attention in material research.

Silica precursors are mostly manufactured from chemical precursor such as tetraethyl orthosilicate(TEOS), methyltriethoxysilane (MTES), tetra ethyl vynilsilane (TEVS), or bis(triethoxysilyl)ethane (BTESE) (Ibrahim et al., 2017), and ethyl silicate-40 (ES-40) (Maimunawaro et al., 2020). These material sources obtain from an inorganic multipurpose chemical compound that is naturally found in quartz, sand, or flint (Moreth et al., 2014). Each precursor can control and tune the silica network. Silica is an important material in thin-film fabrication. Sol-gel is one of the methods that often be utilized to fabricate silica membranes because of simplicity. In the sol-gel process, the hydrolysis and condensation are occurred by reacting alkoxide in an aqueous solution (Elma, Assyaifi, \& Hairullah, 2017). Silanol (Si$\mathrm{OH}$ ) is created through a sol-gel process by employing acid catalysts at hydrolysis reaction, thus produce pore sizes less than $1 \mathrm{~nm}$ in silica thin film (Diniz et al., 2002). Silanol groups will act as a binding site with the water presence, inducing silica matrices collapse and drop the salt rejection in membrane performance because of pore enlargement (Elma et al., 2020; Elma et al., 2020; Elma \& Saputro, 2020, Elma et al., 2015; Rahma et al., 2020b).

To improve the silica membrane strength, several experiments have been done included the organic and inorganic combination materials (Mir et al., 2018), incorporating metal oxide (nickel (Darmawan et al., 2016, Darmawan et al., 2017, Kanezashi \& Asaeda, 2006), cobalt (Liu et al., 2015; Smart et al., 2012) and iron (Darmawan et al., 2015), and carbon template silica (Lestari, et al., 2020, Elma et al., 2020a; Maimunawaro et al., 2020, Rahma et al., 2020a; Syauqiyah et al., 2019). A recent study has shown carbon from pectin of apple peels replaces the use of synthetic carbon as a soft template. It resists the silica matrix collapsing and changed the structure to be more stable for pervaporation application (Pratiwi et al., 2019a; Rahma et al., 2019a; Rampun et al., 2019a). The banana peel was investigated contain a high yield of pectin content until $24.8 \%$ (Khamsucharit et al., 2018). It can be promising ecofriendly carbon. Therefore, in this work, we investigated the performance of interlayer-free carbon template silica membranes for wetland saline water and acid mine drainage desalination.

\section{Methodology \\ Chemicals and materials}

Wetland saline water (WSW) was collected from Muara Halayung village, Indonesia. Acid mine drainage (AMD) taken from Kintap South Kalimantan, Indonesia. Silica pectin sol was prepared by using tetraethyl orthosilicate (TEOS, 99,0\%, Sigma-Aldrich) as silica precursor, ethanol (EtOH, 70\%), dilute nitric acid (0.0008 $\mathrm{M} \mathrm{HNO}_{3}$, Merck), ammonia (0.0003 $\mathrm{M} \mathrm{NH}_{3}$, Merck), pectin from the banana peel, glycerol (85\%, Merck), and aquadest. For membrane support, this study using a macroporous alumina tubular support membrane (Ceramic oxide fabricators, Australia) with pore size $\sim 100 \mathrm{~nm}$.

\section{Membrane synthesis and characteristic}

Firstly, TEOS mixed with EtOH under stirring at $0{ }^{\circ} \mathrm{C}$ for 5 minutes. Secondly, $\mathrm{HNO}_{3}$ was added into solution and refluxed for $1 \mathrm{~h}$ at $50^{\circ} \mathrm{C}$, following by dropwise $\mathrm{NH}_{3}$ under stirring for $2 \mathrm{~h}$ at the same condition. Then checked $\mathrm{pH}$ of pure silica sol until 6 . Pectin dissolved into $5 \mathrm{ml}$ of glycerol and then stirred $360 \mathrm{rpm}$ for 95 minutes at $50{ }^{\circ} \mathrm{C}$. Finally, pectin from the banana peel $(0.5$ and $0.1 \mathrm{wt} \%)$ mixed onto the conducted silica sol for 45 minutes at $0^{\circ} \mathrm{C}$.

Dipped macroporous alumina support membrane into silica-pectin sol to creates a thin film. Membrane dip-coating schematic process shows in Fig..1. All membranes variation were calcined in the air by a furnace at $300{ }^{\circ} \mathrm{C}$ for $0.5 \mathrm{wt} \%$ of pectin and $400{ }^{\circ} \mathrm{C}$ for $0.1 \mathrm{wt} \%$ of pectin. Repeat the dipping process 
and membrane calcined cycle for 4 times. The silica-pectin membranes morphology and thickness were examined using scanning electron microscopy (SEM) tested (Zeiss EVO LS15).

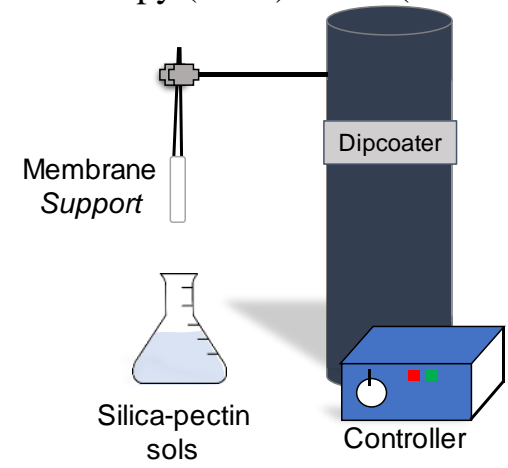

Figure 1. Dip-coating process schematic for silica-pectin membrane fabrication

\section{Membrane pervaporation}

The Pervaporation process was operated as shown in Fig. 2 which tested under room temperature $\left(\sim 25{ }^{\circ} \mathrm{C}\right)$. To keep away from concentration polarization, a peristaltic pump was used. Water flux $\mathrm{F}$ $\left(\mathrm{kg} \cdot \mathrm{m}^{-2} \mathrm{~h}^{-1}\right)$ was measured according to the Eq. (1):

$$
F=\frac{m}{(A . \Delta t)}
$$

Where $\mathrm{m}$ is a permeate mass $(\mathrm{kg})$ accumulated in the cold trap, A is the surface area $(\mathrm{m} 2)$ of the membrane and $\Delta t$ is time operation (h). Salt rejection $\mathrm{R}(\%)$ was obtained based on Eq. (2):

$$
R=\frac{C_{f}-C_{p}}{C_{f}} \times 100 \%
$$

Where $\mathrm{Cf}$ is the salt concentration (wt\%) in the WSW and acid mine drainage water before treatment and $\mathrm{Cp}$ is a salt concentration in water permeate (wt\%) after treatment. It was determined by a conductivity meter (OHAUS) correlated to the conductivity of retentate and permeate.

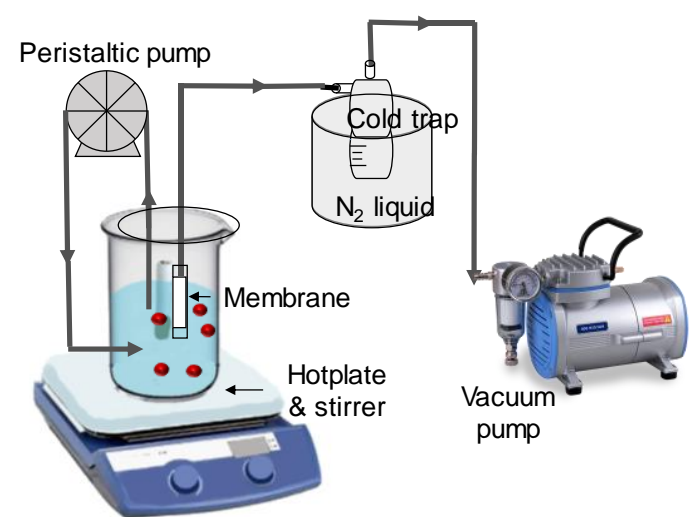

Figure 2. Pervaporation set-up by silica-pectin membranes for water desalination

\section{Result and Discussion \\ characteristic of wetland saline water and acid mine drainage}

Wetland saline water (WSW) and acid mine drainage (AMD) were treated using desalination by silica-pectin membranes. Generally, wetland water and AMD have bad qualities due to its water characteristics. The characteristic of WSW and AMD were displayed in Table 1. Initial WSW and AMD before treatment have $\mathrm{pH}$ below 7. AMD is known as $\mathrm{pH}$ value as low as -3.6 (Plant et al., 2003) and 
containing high numbered of iron. Furthermore, both feed water containing a high concentration of salt above brackish water $(0.3 \% \mathrm{NaCl})$. The concentration of $\mathrm{NaCl}$ in WSW and AMD is 10000 and 500 ppm, successively (Table 1).

Table 1. Characteristic of the wetland saline water and acid mine drainage in South Kalimantan, Indonesia

\begin{tabular}{|c|c|c|c|}
\hline \multirow{2}{*}{ Parameter } & \multicolumn{2}{|c|}{ Result } & \multirow{2}{*}{ Unit } \\
\hline & Wetland saline water & Acid mine drainage & \\
\hline $\mathrm{pH}$ & 6.67 & 4 & - \\
\hline $\mathrm{Fe}$ & N/A & 3.69 & $\mathrm{mg} / \mathrm{L}$ \\
\hline Conductivity & 9350 & 652 & $\mu \mathrm{S} / \mathrm{cm}$ \\
\hline $\mathrm{NaCl}$ & 10000 & 500 & ppm \\
\hline TDS & 5400 & 324 & $\mathrm{mg} / \mathrm{L}$ \\
\hline
\end{tabular}

\section{Membrane morphology}

Silica-pectin membrane morphology from the banana peel is represented by scanning electron microscopy (SEM) image. The silica membranes by carbon induced by pectin $0.5 \%$ and $0.1 \%$ were obtained asymmetric structure illustrated on Fig. 3. Moreover, the surface area of silica-pectin membranes points out bearish or not smooth at all because no interlayer on membrane structure or called interlayerfree. Another reason, it also depends on the factor of the calcination technique (Pratiwi et al., 2019b). Pore size differences between alumina support and a silica-pectin coating layer formed the rough surface on the membrane top layer (Elma, Hairullah, Assyaifi, 2018). RTP technique conducted without ramping rates $\left(1{ }^{\circ} \mathrm{C} / \mathrm{min}\right)$ bring out sudden temperature rise and creates thermal stresses on membranes. Although no crack and no defect are shown on the membrane surface. Other than that, silica-pectin membranes fabrication prepared by RTP technique is way faster than conventional techniques CTP (Pratiwi et al., 2019c, Rahma et al., 2019b).
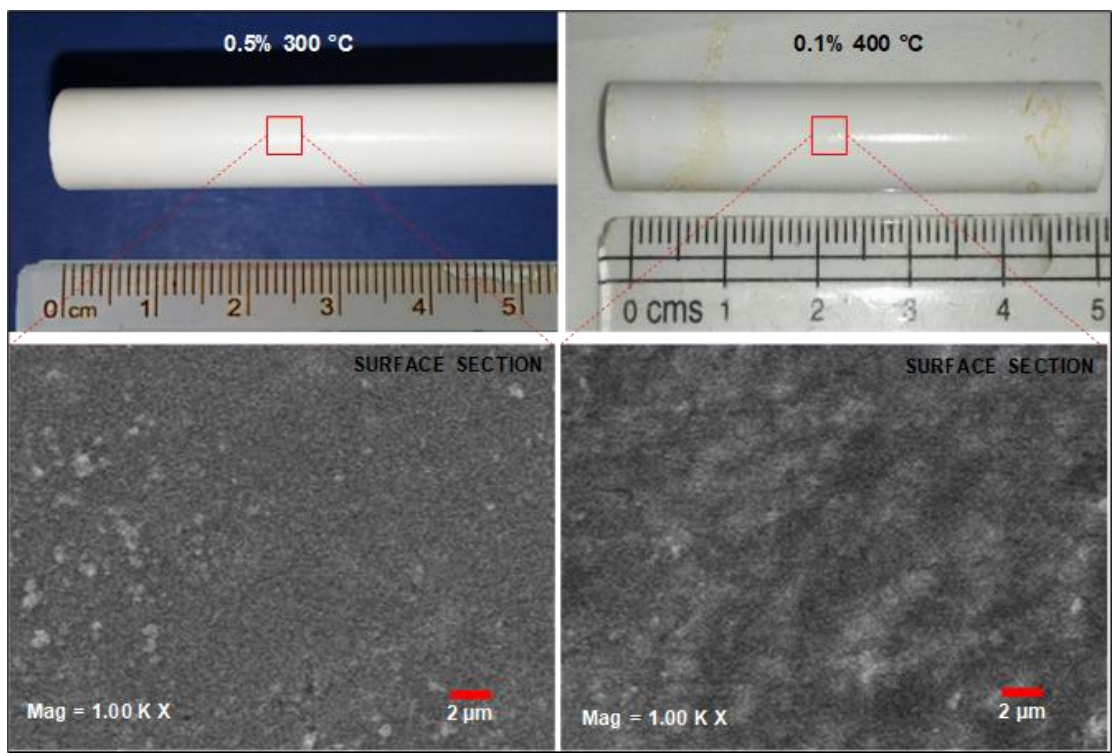

Figure 3. Surface sectional SEM images of silica-pectin membranes (left) $0.5 \%$ pectin calcined at $300{ }^{\circ} \mathrm{C}$ (right) $0.1 \%$ pectin calcined at $400{ }^{\circ} \mathrm{C}$.

The calcination technique contributes to membrane thickness. As shown in Fig. 4, cross-section SEM images of silica-pectin membranes exhibited the thickness of the silica-pectin top layer. Both of 
templating pectin of $0.5 \%$ and $0.1 \%$ into sol-gel was achieved thickness $<2 \mu \mathrm{m}$. The calcined temperature also assisted on silica-pectin layer thickness. Silica-pectin membrane sintered over $300{ }^{\circ} \mathrm{C}$ becomes thinner as displayed in Fig. 4. Solvent and water trapped in silica matrices and then evaporated at 400 ${ }^{\circ} \mathrm{C}$, after that thin layer was created (Elma et al., 2019, Elma et al., 2012, Lestari, et al., 2020, Pratiwi et al., 2019c, Rahma et al., 2019b, Rampun et al., 2019a). The silica-pectin membrane from bananas peel in this work thicker compare to pectin from apples which resulted $<1 \mu \mathrm{m}$ thickness (Rahma et al., 2019b).

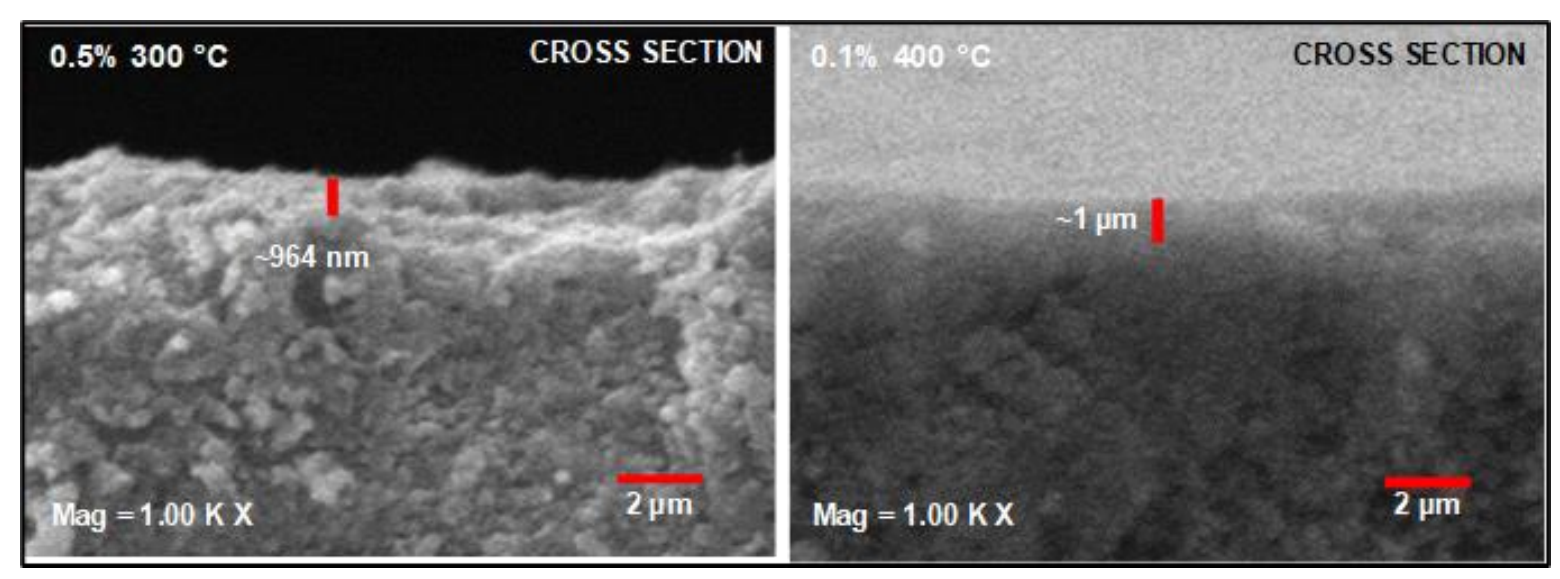

Figure 4. Cross sectional SEM images of silica-pectin membranes (left $0.5 \%$ pectin calcined at $300{ }^{\circ} \mathrm{C}$ (right) $0.1 \%$ pectin calcined at $400{ }^{\circ} \mathrm{C}$.

\section{Membrane performance for desalination of wetland saline water and acid mine drainage}

Silica-pectin membrane from banana peel via pervaporation performed using 2 varied feed i.e. WSW and AMD. Both of Fig. 5A and 5B represent the highest to smallest water flux sorted such as AMD > WSW of feed at room temperature $\left(\sim 25^{\circ} \mathrm{C}\right)$. These results are influenced by the presence numbered of salt and natural organic matter (NOM) in feed water. WSW consists of high salt concentration and NOM, which lead to membrane need extra performances over AMD as feed. Moreover, NOM plays a role in blocking membrane pore and convey membrane performance become heavy, so the water flux going down (Goh et al., 2018, Rahma et al., 2019b). On the other hand, increasing the salt concentration will decrease the thermodynamic activity of water, so does the water flux (Wang et al., 2016).

Attractively, carbon templated silica membrane by loaded of $0.5 \%$ pectin calcined at $300{ }^{\circ} \mathrm{C}$ shows the highest water flux of AMD of $10.8 \mathrm{~kg} \cdot \mathrm{m}^{-2} \cdot \mathrm{h}^{-1}$. Whereas the lowest permeate flux was produced from WSW as feed at room temperature $\sim 25^{\circ} \mathrm{C}$ by adding pectin template $0.1 \%$ calcined at $400{ }^{\circ} \mathrm{C}$. Increasing of carbon concentration for templates tend to form micelles and precipitate if in excess on silica sol-gel (Raman, Anderson, \& Brinker, 1996). In this case, addiction of pectin of $0.1 \%$ and $0.5 \%$ into silica solgel was obtained water flux increase as well. This was also mentioned in Elma et al. (2015) which used variations of $\mathrm{NaCl}$ concentration $(0.3-7.5 \% \mathrm{NaCl})$ as the feed. The high concentration of contaminants in membrane feed water results in concentration polarization which hurts reducing membrane performance (Elma et al., 2012). 

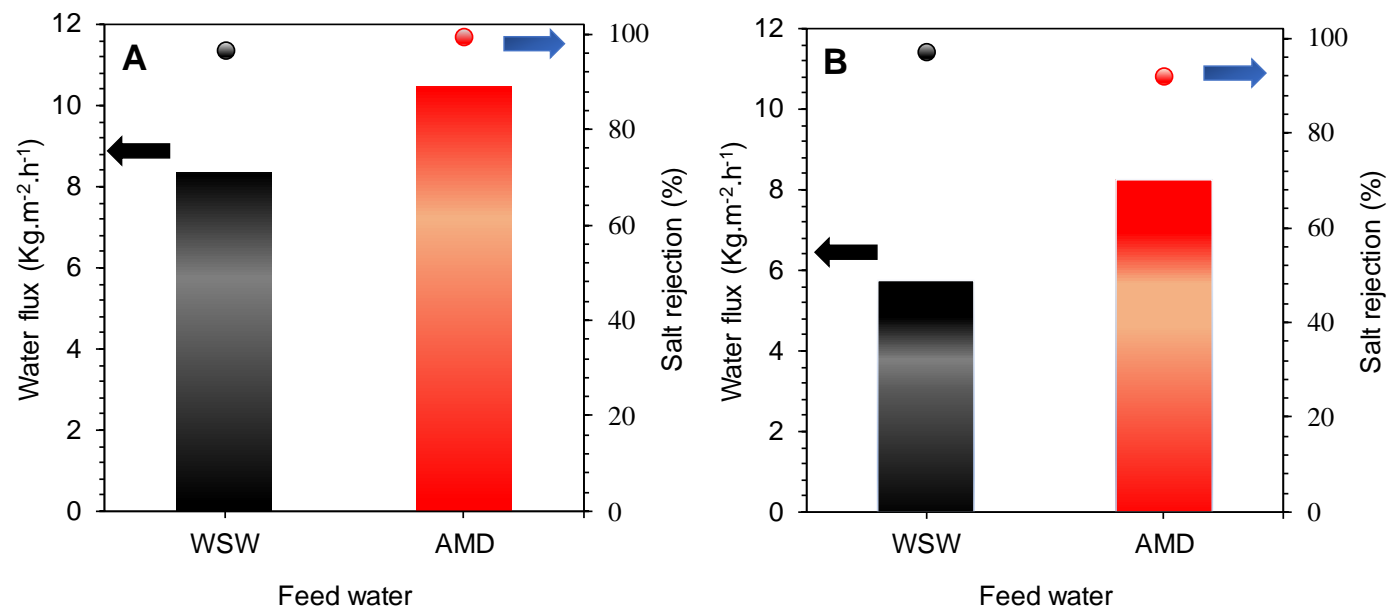

Figure 5. Performance of silica-pectin membranes for desalination of WSW and AMD (A) $0.5 \%$ pectin calcined at $300{ }^{\circ} \mathrm{C}$ (B) $0.1 \%$ pectin calcined at $400{ }^{\circ} \mathrm{C}$.

Rejection of salt for all feedwater showed very well at all pectin loading (0.1-0.5\%). Based on Fig. $5 \mathrm{~A}$, salt rejections in all feeds are high $>98 \%$ for pectin $0.5 \%$ calcined at $300{ }^{\circ} \mathrm{C}$. However, salt rejection of pectin templates of $0.1 \%$ in silica membrane resulted slightly lower of above $95 \%$ (Fig. 5B). The rejection of WSW is very good even though the silica-pectin membrane containing foulant which is the presence of a layer of humic compounds. According to Kim et al. (2009) organic fouling can increase or decrease salt rejection depending on the characteristics of the membrane used.

The membrane in this work presented approvingly as compared to previous carbon template silica membranes reported in the literature assorted in Table 1. For similar testing condition (WSW as feed; $\left.25^{\circ} \mathrm{C}\right)$, it is observed the banana pectin membrane in this work $\left(8.3 \mathrm{~kg} \cdot \mathrm{m}^{-2} \cdot \mathrm{h}^{-1} ;>98 \%\right)$ delivered a water flux 7 fold higher than pure silica membrane $\left(1.19 \mathrm{~kg} \cdot \mathrm{m}^{-2} \cdot \mathrm{h}^{-1} ; 85 \%\right)$ (Elma, Hairullah, \& Marhamah, 2018), and at least 5 times high compare P123 template membrane $\left(1.67 \mathrm{~kg} \cdot \mathrm{m}^{-2} \cdot \mathrm{h}^{-1} ; 96 \%\right)$ (Elma et al., 2018) and also 2 fold time than apple pectin membrane (4.45 kg. $\mathrm{m}^{-2} \cdot \mathrm{h}^{-1}$; 99\%) (Rahma et al., 2019b), whilst salt rejection were high and comparable.

Table 2. Performance of silica base membrane for desalination

\begin{tabular}{|c|c|c|c|c|c|}
\hline Membrane & Condition testing & Feed & $\begin{array}{l}\text { Flux }\left(\mathbf{k g} \cdot \mathbf{m}^{-}\right. \\
\left.{ }^{2} \cdot \mathrm{h}^{-1}\right)\end{array}$ & $\begin{array}{l}\text { Rejec- } \\
\operatorname{tion}(\%)\end{array}$ & Ref \\
\hline pectin banana peel & $\begin{array}{l}\mathrm{RTP}, 25^{\circ} \mathrm{C}(0.1 \& 0.5 \% \text { of pec- } \\
\text { tin })\end{array}$ & WSW & $5.7-8.3$ & $>98$ & This work \\
\hline pectin banana peel & $\begin{array}{c}\mathrm{RTP}, 25^{\circ} \mathrm{C}(0.1 \& 0.5 \% \text { of pec- } \\
\text { tin })\end{array}$ & AMD & $8.2-10.8$ & $>95$ & This work \\
\hline pectin apple peel & $\mathrm{RTP}, 25^{\circ} \mathrm{C}(0.5 \%$ of pectin $)$ & WSW & 4.45 & 99 & $\begin{array}{l}\text { (Rahma, } \\
\text { Elma et al., } \\
\text { 2019b) }\end{array}$ \\
\hline P123 & $\mathrm{RTP}, 25^{\circ} \mathrm{C}$ & WSW & $1.25-1.67$ & $66-96$ & $\begin{array}{l}(\text { Elma, } \\
\text { Fitriani et } \\
\text { al., 2018) }\end{array}$ \\
\hline silica & $\mathrm{RTP}, 25-60{ }^{\circ} \mathrm{C}$ & WSW & $0.84-1.19$ & $70-85$ & $\begin{array}{c}\text { (Elma, } \\
\text { Hairullah } \\
\text { et al., } \\
2018)\end{array}$ \\
\hline
\end{tabular}


The purity of permeate water was assessed by evaluating the salt concentration calculated from a standard curve based on the measurements of conductivity. Figure 6 demonstrates that the permeate salt concentration was calculated to be 110-135 and 4-104 ppm for WSW and AMD feed solutions, respectively. These are well below recommended total dissolved salt concentrations of 600 ppm for potable water according to the World Health Organization. These results clearly show that the silica-pectin membranes prepared from the banana peel in this work can be used to treat wetland saline water and acid mine drainage at room temperature conditions with excellent performance.

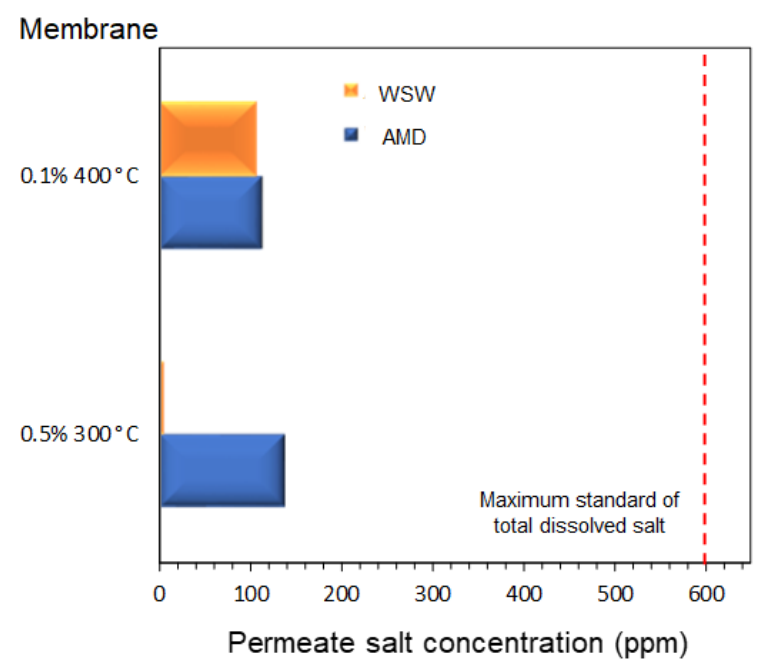

Figure 6. Permeate salt concentration as a function of the membrane silica-pectin concentration for desalination of WSW and AMD.

\section{Conclusion}

Silica-pectin membranes have been successfully developed by inducing pectin from banana peel into silica sol. Pectin concentration of $0.5 \%$ has outstanding performance for desalination. Silica-pectin membrane $\left(0.5 \%\right.$ pectin; $\left.300{ }^{\circ} \mathrm{C}\right)$ delivered high water flux of $8.3 \mathrm{~kg} \cdot \mathrm{m}^{-2} \cdot \mathrm{h}^{-1}(\mathrm{WSW})$ and $10.8 \mathrm{~kg} \cdot \mathrm{m}^{-2} \cdot \mathrm{h}^{-1}$ (AMD). All salt rejection achieved over $98 \%$. Moreover, the membranes can effectively produce potable water in these conditions because it reduces permeate salt concentration until below $600 \mathrm{ppm}$. Also, the silica-pectin membrane is favorable to be developed in wetland saline water and acid mine drainage desalination, considering that templating pectin as a carbon precursor to upgrade the silica membrane performance.

\section{Acknowledgment}

Authors thanks to $\mathrm{M}^{2} \mathrm{ReG}$ (Material and Membranes Research Group) for the facilities provided. Muthia thanks to Applied Research Universities Grant 2019-2020, Thesis Magister Grant 2020, World Class Research Grant 2021-2022 the Directorate of Research and Community Service, the Ministry of Research and Technology/the National Agency for Research and the Innovation Republic of Indonesia, and Lambung Mangkurat University Research Grant 2020. Lambung Mangkurat University Grant 2020.

\section{References}

Adoor, S.G., Manjeshwar, L.S., Bhat, S. D., \& Aminabhavi, T. M. (2008). Aluminum-rich zeolite beta incorporated sodium alginate mixed matrix membranes for pervaporation dehydration and esterification of ethanol and acetic acid. Journal of Membrane Science, 318(1), 233-246.

Lestari, R. A., Elma, M., Rampun, E. L. A., \& Sumardi. (2020). Functionalization of Si-C Using TEOS (Tetra Ethyl Ortho Silica) as Precursor and Organic Catalyst. E3S Web Conf., 148(17), 07008, doi: 10.1051/e3sconf/202014807008

Crespo, J. and Brazinha, C. 2015. Fundamentals of pervaporation. Pervaporation, Vapour Permeation and Membrane Distillation. Elsevier. pp. 3-17. 
Darmawan, A., Karlina, L., Astuti, A., \& Sriatun, S. (2016). Structural evolution of nickel oxide silica sol-gel for the preparation of interlayerfree membranes. Journal of Non-Crystalline Solids, 447, 9-15. doi: 10.1016/j.jnoncrysol.2016.05.031

Darmawan, A., Karlina, L., Astuti, Y., Sriatun, Wang, D. K., Motuzas, J., \& da Costa, J. C. D. (2017). Interlayer free - nickel doped silica membranes for desalination. IOP Conference Series: Materials Science and Engineering, 172(1), 012001.

Darmawan, A., Motuzas, J., Smart, S., Julbe, A., \& da Costa, J C. D. (2015). Binary iron cobalt oxide silica membrane for gas separation. Journal of Membrane Science, 474, 32-38.

Diniz Da Costa, J.C. (2000). Synthesis and characterisation of molecular sieve silica (MSS) membranes.

Diniz da Costa, J.C., Lu, G.Q., Rudolph, V., \& Lin, Y.S. (2002). Novel molecular sieve silica (MSS) membranes: characterisation and permeation of single-step and two-step sol-gel membranes. Journal of Membrane Science, 198(1), 9-21.

Ellis, F. P. K. (2004). Fabrication of random hole optical fiber preforms by silica sol-gel processing. Virginia Tech.

Elma, M., Assyaifi, Z. L., \& Hairullah. (2017). Fabrication of Silica Thin Film as Membranes Coating from Precursor of TEOS (Tetra Ethyl Ortosilicate). Quantum Jurnal Inovasi Pendisikan Sains, 8(2), 78-82.

Elma, M., Ayu, R., Rampun, E. L. A., \& Annahdliyah, S. (2019). Fabrication of interlayer-free silica-based membranes - effect of low calcination temperature using an organo-catalyst. Membrane Technology, 2019(2), 6-10.

Elma, M., Fitriani, Rakhman, A., \& Hidayati, R. (2018). Silica P123 membranes for desalination of wetland saline water in South Kalimantan. IOP Conference Series: Earth and Environmental Science, IOP Publishing.

Elma, M., Hairullah, \& Assyaifi, Z. L. (2018). Desalination Process via Pervaporation of Wetland Saline Water. IOP Conference Series: Earth and Environmental Science, IOP Publishing.

Elma, M., Rahma, A., Pratiwi, A.E., \& Rampun, E.L.A. (2020a). The Performance of Membranes Interlayer-Free Silica-Pectin Templated for Seawater Desalination via Pervaporation Operated at High Temperature of Feed Solution. Materials Science Forum, 981, 349-355.

Elma, M., Rahma, A., Pratiwi, A.E., \& Rampun, E. L. A. (2020). Coagulation as pretreatment for membrane-based wetland saline water desalination. Asia-Pacific Journal of Chemical Engineering n/a(n/a) e2461.

Elma, M. et al. (2020). Carbon templated strategies of mesoporous silica applied for water desalination: A review. Journal of Water Process Engineering, 38, 101520 .

Elma, M., Riskawati, N., \& Marhamah. (2018). Silica membranes for wetland saline water desalination: performance and long term stability. IOP Conference Series: Earth and Environmental Science 175(1) 012006.

Elma, M., \& Saputro, G.S. (2020). Performance of Cobalt-Silica Membranes through Pervaporation Process with Different Feed Solution Concentrations. Materials Science Forum, 981, 342-348.

Elma, M., Setyawan, H., Rahma, A., \& Pratiwi, A. E. (2019). Fabrication of interlayer-free P123 caronised template silica membranes for water desalination: Conventional Versus Rapid Thermal Processing (CTP vs RTP) Techniques. IOP Conference Series: Materials Science and Engineering, IOP Publishing.

Elma, M., Wang, D.K., Yacou, C., \& Costa, J.C.D.d. (2015). Interlayer-Free P123 Carbonised Template Silica Membranes for Desalination with Reduced Salt Concentration Polarisation. Journal of Membrane Science,475, 376-383.

Elma, M., Yacou, C., Wang, D. K., Smart, S., \& da Costa, J. C. D. (2012). Microporous Silica Based Membranes for Desalination. Water, 4(3), 629-649. https://doi.org/10.3390/w4030629

Goh, P.S., Lau, W.J., Othman, M.H.D., \& Ismail, A.F. (2018). Membrane fouling in desalination and its mitigation strategies. Desalination, 425(Supplement C), 130-155.

Ibrahim, S.M., Nagasawa, H., Kanezashi, M., \& Tsuru, T. (2017). Organosilica bis(triethoxysilyl)ethane (BTESE) membranes for gas permeation (GS) and reverse osmosis (RO): The effect of preparation conditions on structure, and the correlation between gas and liquid permeation properties. Journal of Membrane Science, 526, 242-251.

Kaddour Djebbar, M., Nguyen, Q.T., Clément, R., \& Germain, Y. 1998. Pervaporation of aqueous ester solutions through hydrophobic poly(ether-block-amide) copolymer membranes. Journal of Membrane Science, 146(1), 125-133.

Kanezashi, M., \& Asaeda, M. (2006). Hydrogen permeation characteristics and stability of Ni-doped silica membranes in steam at high temperature. Journal of Membrane Science, 271(1), 86-93.

Khamsucharit, P., Laohaphatanalert, K., Gavinlertvatana, P., Sriroth, K., \& Sangseethong, K. (2018). Characterization of pectin extracted from banana peels of different varieties. Food Science and Biotechnology, 27(3), 623-629. doi: 10.1007/s10068-017-0302-0

Kim, S., Lee, E., Lee, E., \& Sarp, S. (2009). Enhanced or reduced concentration polarization by membrane fouling in seawater reverse osmosis (SWRO) processes. Desalination, 247(1), 162-168. doi: 10.1016/j.desal.2008.12.021

Lestari, R.A. et al. 2020. Organo silica membranes for wetland saline water desalination: Effect of membranes calcination temperatures. E3S Web Conf. 14807006 
Liu, L., Wang, D. K., Martens, D. L., \& Smart, S. (2015). Interlayer-free microporous cobalt oxide silica membranes via silica seeding sol-gel technique. Journal of Membrane Science, 492, 1-8.

Maimunawaro, Rahman, S. K., Rampun, E. L. A., \& Rahma, A. (2020). Deconvolution of carbon silica templated thin film using ES40 and P123 via rapid thermal processing method. Materials Today: Proceedings. doi: 10.1016/j.matpr.2020.01.195

Mir, S. H., Nagahara, L. A., Thundat, T., \& Mokarian-Tabari, P. (2018). Review-Organic-Inorganic Hybrid Functional Materials: An Integrated Platform for Applied Technologies. Journal of the Electrochemical Society, 165(8), B3137-B3156.

Moreth, K. et al. 2014. Biglycan-triggered TLR-2-and TLR-4-signaling exacerbates the pathophysiology of ischemic acute kidney injury. Matrix Biology, 35, 143-151. https://doi.org/10.1016/j.matbio.2014.01.010

Nurofiq, H.F., Bisri, M., Soemarno, Mursyid, A., Rubiantoro, P., \& Fajar, H. M. (2016). The effect of acid mine water on ground water hydrochemical, in mantewe, tanah bumbu regency, South Kalimantan, Indonesia. International Journal of Applied Chemistry, 12(3), 293-308

Plant, J.A. et al. (2003). 9.02 - Arsenic and Selenium. In H. D. Holland and K. K. Turekian eds. Treatise on Geochemistry. Oxford, Pergamon. pp. 17-66.

Pratiwi, A. E., Elma, M., Putra, M. D., Mirwan, A., Rahma, A., \& Rampun, E. L. A. (2019a). Innovation of carbon from pectin templated in fabrication of interlayer-free silica-pectin membrane. Jurnal Kimia Sains dan Aplikas, 22(3), 6.

Pratiwi, A. E., Elma, M., Putra, M. D., Mirwan, A., Rahma, A., \& Rampun, E. L. A. (2019b). Innovation of Carbon from Pectin Templated in Fabrication of Interlayer-free Silica-Pectin Membrane. Jurnal Kimia Sains dan Aplikasi 22(3), 93-98.

Pratiwi, A. E., Elma, M., Putra, M. D., Mirwan, A., Rahma, A., \& Rampun, E. L. A. (2019c). Deconvolution of pectin carbonised template silica thin-film: synthesis and characterisation. Membrane Technology, 2019(9), 5-8.

Rahma, A. et al. (2019a). Removal of natural organic matter for wetland saline water desalination by coagulation-pervaporation. Journal of Scienctific \& Applied Chemistry, 22(3), 8.

Rahma, A. et al. (2019b). Removal of natural organic matter for wetland saline water desalination by coagulation-pervaporation. Jurnal Kimia Sains dan Aplikasi, 22(3), 85-92.

Rahma, A., Elma, M., Pratiwi, A. E., \& Rampun, E. L. (2020a). Performance of interlayer-free pectin template silica membranes for brackish water desalination. Membrane Technology, 2020(6), 7-11.

Rahma, A., Elma, M., Rampun, E. L. A., Pratiwi, A. E., Rakhman, A., \& Fitriani. (2020b). Rapid Thermal Processing and Long Term Stability of Interlayer-free Silica-P123 Membranes for Wetland Saline Water Desalination. Advanced Research in Fluid Mechanics and Thermal Sciences, 71(2), 1-9.

Raman, N.K., Anderson, M.T., \& Brinker, C.J. (1996). Template-Based Approaches to the Preparation of Amorphous, Nanoporous Silicas. Chemistry of Materials, 8(8), 1682-1701.

Rampun, E.L.A., Elma, M., Rahma, A., \& Pratiwi, A.E. (2019a). Interlayer-free silica-pectin membrane for sea-water desalination. Membrane Technology, 2019(12) 5-9.

Rampun, E. L. A., Elma, M., Syauqiah, I., Putra, M. D., Rahma, A., \& Pratiwi, A. E. (2019b). Interlayer-free silica pectin membrane for wetland saline water via pervaporation. Jurnal Kimia Sains dan Aplikasi,22(3), 6.

Smart, S., Vente, J.F., \& Diniz da Costa, J.C. 2012. High temperature H2/CO2 separation using cobalt oxide silica membranes. International Journal of Hydrogen Energy, 37(17), 12700-12707.

Syauqiyah, I., Elma, M., Putra, M. D., \& Rahma, A. (2019). Interlayer-free Silica-carbon Template Membranes from Pectin and P123 for Water Desalination. MATEC Web Conf. 280, 03017.

Van der Bruggen, B. and Luis, P. (2015). Chapter Four - Pervaporation. In S. Tarleton ed. Progress in Filtration and Separation. Oxford, Academic Press. pp. 101-154.

Wang, Q. et al. (2016). Desalination by pervaporation: A review. Desalination, 387, 46-60. 